logos_i_ethos_2015_2_(39), s. 97-115

DOI: http://dx.doi.org/10.15633/lie.1538

Grzegorz Hołub

Uniwersytet Papieski Jana Pawła II w Krakowie

\title{
Karol Wojtyła on the metaphysics of the person
}

Karol Wojtyła's personalism, though original and novel, is associated with, and even rooted in, several modern philosophical projects. In this way the Polish philosopher conducted a kind of intellectual conversation with various thinkers of

Grzegorz Hołub is an associate professor of philosophy at the Pontifical University of John Paul II in Krakow. Among his publications are two books Problem osoby we współczesnych debatach bioetycznych and Osoba w labiryncie decyzji moralnych. Bioetyka w perspektywie personalistycznej. the past and constructed his own philosophical stance. However, it does not mean that Wojtyła uncritically accepted the philosophical vocabulary used by previous thinkers. Indeed he had his own personal message to convey, worded in his own specific language. This is why he used various concepts and terms coined by great figures in the history of philosophy but attempted to work out a new perspective and, at times, a whole new meaning for some of them. In his philosophical language there are some notions, which underwent a kind of serious sematic shift. The concept of suppositum is one of these.

The meaning of suppositum is close to the meaning of subject but it has a clearly metaphysical character. Thus when we refer this notion to the human being we are going to claim that the human being is the subject of its own existence and actions, and as such can be investigated within a theory of being. Wojtyła was aware that a human person cannot be adequately explained within the sole concept of suppositum but, at the same time, he hoped that this notion brings with it an important message concerning the nature of personhood. Although the term is a part of ancient and medieval heritage, it plays a vital role in contemporary thinking of the human person. Having said that, we must point to one 
important circumstance: the employment of the concept of suppositum carried out by Wojtyła was not a literal transmission of the pre-modern way of philosophizing into contemporary philosophy. Keeping its original significance, the notion is perceived through the prism of modern and contemporary knowledge about the person. And this circumstance allows us to claim that suppositum is remade and enriched by Wojtyła's attempts.

In this paper, I would like, first, to sketch Wojtyła's approach to metaphysics. Second, I would like to penetrate the meaning of the term and its place in the philosophy of the human person advanced by the Polish thinker. Finally, I will be trying to look critically at Wojtyła's endeavor and ask how its understanding and content can be strengthened by an original concept of substance worked out by W. Norris Clarke. Both Karol Wojtyła and Norris Clarke were adherents of Thomistic philosophy, although in various degrees. Clarke is more metaphysically-oriented so he can bring some help to Wojtyła whose writings seldom directly address metaphysical themes. The general aim of the paper is not only to sketch Wojtyła's thinking about suppositum but also to contribute some insight into the metaphysics of the person.

\section{Wojtyła and metaphysics}

When we look at ideas set out by John Paul II concerning a need for metaphysics, we have no doubt that he appreciated the role of a first philosophy in a broader culture, and specifically in the philosophy of the human person. In his encyclical letter Fides et ratio, the "later Wojtyła" underlines without hesitation "the need for a philosophy of genuinely metaphysical range, capable, that is, of transcending empirical data in order to attain something absolute, ultimate and foundational in its search for truth." Such a first philosophy is not opposed to a genuine reflection on the human being but can be helpful and complementary. As he claims, "metaphysics should not be seen as an alternative to anthropology, since it is metaphysics which makes it possible to ground the concept 
of personal dignity in virtue of their spiritual nature. In a special way, the person constitutes a privileged locus for the encounter with being, and hence with metaphysical enquiry." In the light of these clear declarations, Wojtyła can be perceived as a strong metaphysician, or at least someone who decisively favors a metaphysical approach in philosophy as such. But what about the "earlier Wojtyła"? Was he equally determined to promote this kind of philosophizing, and, if so, how successful was he in this respect?

As a young student of theology Karol Wojtyła was impressed by Thomistic philosophy, and especially by Thomistic metaphysics. Talking about it later in his life, he acknowledged that studies in first philosophy had helped him to acquire "a new vision of the world" and led him to a discovery, which "has remained the basis of intellectual structure in his life." This discovery underpinning his intellectual endeavors appeared from time to time in Wojtyła's early works. His first scholarly achievement was concerned with the question of faith in the thought of St. John of the Cross. Metaphysics was indirectly present here because contact with God and an endeavor to understand it presupposes the question of being. Later Wojtyła turned to moral theology. In his work on Max Scheler and the suitability of his ethics for Catholic moral theology, the Polish thinker made reference to metaphysical issues, for instance when he critiqued Scheler's failure to recognize the "substance" of the person. ${ }^{4}$ When he crossed the threshold into philosophical ethics, Wojtyła quite often undertook metaphysical analyses in order to shed some light on the categories needed in ethical investigation. Thus we notice that he gave some scholarly attention to concepts like nature ${ }^{5}$ and the good. ${ }^{6}$ Or when talking about the sexual drive, he pointed to metaphysics as the final ground

Ibid.

3 A. Frossard, "Be not afraid": pope John Paul II speaks out on his life, his beliefs, and his inspiring vision for humanity, trans. J. R. Foster, New York 1984, p. 18.

$4 \quad$ K. Wojtyła, Ocena możliwości zbudowania etyki chrześcijańskiej przy założeniu systemu Maxa Schelera, [in:] id., Zagadnienie podmiotu moralności, Lublin 1991, p. 120.

For and example of this see: id., Elementarz etyczny, Lublin 1999, p. $33 \mathrm{ff}$.

6 For and example of this see: id., Wykłady lubelskie, Lublin 1985, p. 141-144. 
to the proper understanding of it. ${ }^{7}$ Generally, he was convinced that the philosophy of consciousness must be supplemented by the philosophy of being. He voiced this when he talked about a realistically understood consciousness connected with the person's being which is a condition of not making this being into an autonomous, enclosed in itself, subject of activity. ${ }^{8}$ But through this entire period, although conscious of the importance of first philosophy, Wojtyła did not develop a systematic project of metaphysics in general, nor the metaphysics of the human person in particular.

Some scholars claim that Karol Wojtyła never attempted to formulate his own concept of metaphysics of the person. ${ }^{9}$ This is probably true but only to a point. On the one hand, the Polish philosopher did not write a paper, let alone a book, which was entirely dedicated to the philosophy of being. This suggests that he was basically involved in other ways of philosophizing. His analyses on the person are basically conducted along a phenomenological path, and the issue of being is here presupposed but not adequately explained. This raised some criticism at the very beginning, when his main work The acting person ${ }^{10}$ was published for the first time. ${ }^{11}$ But on the other hand, he was convinced of the need and even

7 In his Love and responsibility he states the following, "but if the sexual urge has an existential character, if it is bound up with the very existence of the human person - that first and most basic good - then it must be subject to the principles which are binding in respect of the person." See K. Wojtyła, Love and responsibility, trans. H. T. Willetts, San Francisco 1981, p. 52. (Polish original is: Miłość i odpowiedzialność, Lublin 1960).

$8 \quad$ K. Wojtyła, In search of the basis of perfectionism in ethics, [in:] id., Person and community. Selected essays, trans. T. Sandok, New York 1993, p. 54.

$9 \quad$ See e.g. A. J. Reimers, Karol Wojtyła's aims and methodology, delivered at the conference Christianity Confronts Modernity, December 12-14, 2013, University of Notre Dame (USA), publication pending.

${ }_{10}$ The acting person is the English edition of Osoba i czyn, which is cited in the following notes.

11 Polish philosopher of Thomistic orientation Krąpiec commenting on the book denied that Wojtyła had managed to formulate an adequate philosophical anthropology. He pointed to a lack of analyses of human activities in essential contexts of human life. Krąpiec called Wojtyła's enterprise "an aspect anthropology", "anthropology for the use of ethicist and moralist", "ethical anthropology”. See M. A. Krąpiec, Książka kardynała Karola Wojtyły monografią osoby jako podmiotu moralności, "Analecta Cracoviensia" 5-6 (1973-1974), p. 57-58. 
the necessity of metaphysics in the philosophy of the human person. In this paper we will be trying to demonstrate and analyze some passages where attempts at carrying out this need and necessity are undertaken.

Preliminary we can ask about Karol Wojtyła's sources of metaphysical formation. We are interested in these circumstances, specifically as far as the concept of suppositum is concerned. There is no doubt that our philosopher was educated in Aristotelian and Thomistic philosophy, dominant at that time in his environment. As the later Wojtyła mentioned to André Frossard, he had studied metaphysics from a book by Kazimierz Wais, a Thomistic philosopher in pre-war Poland. Let us treat this position as a prime source of the metaphysical knowledge entertained by Wojtyła in his later activities. In this book on ontology and metaphysics we find some basic concepts, including notions referring to the human being. As was the custom of traditional Thomistic philosophers, Wais distinguishes the concept of the individual (individuum) from the notion of the person - individual with reason. The latter is also called suppositum rationale, but a sole suppositum is equivalent to the term individua substantia (also appearing in the Boethian definition of the person). Understandably the notion of suppositum is broader than suppositum rationale because - as Wais observes - "any person is an individual but not every individual is a person."12 In the anthropological analyses of Wojtyła, there is a sole concept of suppositum without a qualifier rationale. It is thus because the philosopher is basically concerned with human subjects and has no doubt as to their rational powers and faculties. Nevertheless, the person is for him merely a starting point and we can underline two reasons explaining this attitude. First, Wojtyła tries to demonstrate the insufficiency of the metaphysical approach to the human individual, that is, to prove that without experience we cannot achieve the complete picture of the person. Second, the suppositum itself is a richer reality than classical scholastic analyses reveals. In this paper, we will be basically concerned with the latter. 


\section{Personhood and suppositum}

In this part of our analyses, we will be following Wojtyła's expressions concerning the concept of suppositum as far as the structure of personhood is concerned. First, we will focus on negative expressions, namely expressions by which our philosopher proves an insufficiency in the notion for an adequate understanding of the person. Second, we will try to sketch a positive role of suppositum in the constitution of the person. In this part, we will also point to the further development of the concept as set out by Wojtyła in his later works, namely papers published after The acting person.

To be a person is something more than to be a suppositum. Such is the first and foremost part of Wojtyła's philosophical account of the human being. The suppositum is a subject of existence and action and this thesis stems from a long philosophical tradition to which our philosopher subscribes. But this kind of subjectivity points only to an objective meaning of the subject, and all spheres of subjective experience are put aside. The Polish philosopher expresses this view quite openly, saying that, "the notion of suppositum passes over an aspect of consciousness due to which a particular human being - a subject being an object - experiences himself as a subject. Thus he experiences his subjectivity and this experience provides him with a ground to term himself with a pronoun ' $\left[.{ }^{\prime 213} \mathrm{In}\right.$ other words, the latter is not a reality separate from the suppositum but encompasses it as its own part. The integrally understood "I" besides an ontic subjectivity (the suppositum), consists of the experienced subjectivity. ${ }^{14}$ In short, the complete subjectivity of the person goes well beyond the suppositum alone.

13 K. Wojtyła, Osoba i czyn, [in:] id., „Osoba i czyn” oraz inne studia antropologiczne, Lublin 1994, p. 93. Later, Wojtyła specifies that the term "experience" includes semantically "consciousness". He claims, "if this being, that is a real individual object in its basic ontic structure, is equivalent to a reality which in traditional philosophy was called the suppositum, then without consciousness this suppositum cannot be constituted as 'I"' Ibid., p. 95.

14 Ibid., p. 93. 
The meaning of ontic subjectivity is close to the concept of individual substance or individuated nature, which constitues part of the Boethian definition of the person. Another important feature of this substance is that it has a rational nature. These theses about the person - as Wojtyła claims - are necessary but insufficient. ${ }^{15}$ The person possesses in herself a kind of fullness, which cannot be adequately explicated by metaphysical terms alone. They merely introduce into the reality of the person and as such are important but they provide too general a framework, which is basically insufficient for the depth and complexity of the person.

Nevertheless, the suppositum can be perceived from a positive and constructive side. Having in mind all previous remarks on its insufficiency, we can also emphasize the important role it plays in the constitution of the person. This role, as we mentioned above, is quite complex. Wojtyła is aware of it and unfolds its role gradually.

The Polish philosopher points initially to a way in which it is given epistemologically to a subject. He claims that the human being has a kind of basic experience allowing her to establish that she is the subject of existence and action. This kind of experience has a very fundamental and holistic character. Wojtyła expresses this conviction this way, "any human being, including myself, is given in a whole that is a simple experience as the individual real being, as the subject of existence and action (that is as the suppositum.)"16 Thus we can argue that the suppositum is not so much inferred from other concepts but has experiential foundations. Of course, a subsequent proper understanding of the notion engages our rational powers and faculties, and its mature comprehension is the fruit of our sophisticated analyses.

Suppositum cannot be understood as an abstract ground upon which personal characteristics are inserted. It does have its vital participation in a personal constitution of any human individual. Even if we can ascribe an analogous suppositum to other non-human entities, the human suppositum is a suppositum of 'who' but not of 'what'. As our philosopher 
emphatically underlines, "the person is the suppositum but very different from others surrounding the human being in a perceptible world. This otherness, this proportion or rather disproportion indicated by pronouns "who" and "what", permeates into the very root of being who is the subject" ${ }^{\prime \prime}$. Wojtyła is convinced that, in a family of entities, there are wide varieties and even when we claim that many beings can be characterized in terms of suppositum, at the same time, we must employ analogous thinking.

A factor, which introduces the vital difference between the human suppositum and others, is the way of existing (esse). It has a clear personal mark and goes beyond a "marker" of the existence of an individuated nature. The human suppositum reveals and manifests a kind of fullness typical for the person in all his uniqueness and unrepeatability. Wojtyła, taking into account our cognitive abilities, claims that, "the person allows to identify himself as the suppositum when an adequate analogy is employed. The suppositum of 'who' reveals not only similarity but also a difference and distance from any suppositum of 'what."'18

The personal suppositum reveals its specific character when we take into account personal dynamism. On the level of various dynamisms, we obtain a clear picture of the unique profile of the person's metaphysical subjectivity. Thus the latter is the ground of both "happenings" and "personal acts." A complex potentiality initiating two fundamental activities in the suppositum of the person is present: first, what takes place despite someone's rationality and freedom, and second, efficacy/operativity, which stems from a free and rationally informed self-determination. ${ }^{19}$ What is important here is to point to a kind of coherence of these two dynamisms, despite their differences concerning personal and intentional involvement. Wojtyła would tend to characterize this binding suppositum as a common source for the whole person. For him, it is a principle of unity and non-contradiction. Our philosopher puts it this way, "on

$\begin{array}{ll}17 & \text { Ibid., p. } 123 . \\ 18 & \text { Ibid. } \\ 19 & \text { Ibid., p. } 124 .\end{array}$ 
the ground of suppositum difference and opposition between someone's acts and happenings [...] yield because of the obvious unity and identity of the human being. It is he who acts. And when something happens in him, he - a personal 'somebody' - does not act, but nevertheless all dynamism of happenings is equally his property as well as the dynamism of acts. He - a personal 'somebody' - remains at the beginning of the happenings taking place in him as well as at the beginning of acts which he carries out as a perpetrator."20

In further developments of the meaning of this concept, Wojtyła clearly stresses both a continuation of the ancient and medieval heritage, and a modern and contemporary contribution to the understanding of suppositum. The former factor already seems to be obvious for us. The latter demands some comments and analyses. Many philosophers drawing on concepts that originated in ancient and medieval philosophy do this in the context of projects developed by modern and contemporary philosophy. This seems to be the case of the Polish thinker. He considers the notion of suppositum taking into account essential Kantian distinctions. This is especially evident when Wojtyła undertakes a new attempt to describe and define this ancient notion. He asserts: "this concept serves to express the subjectivity of the human being in the metaphysical sense. By 'metaphysical', I mean not so much 'beyond-the-phenomenal' as 'through-the-phenomenal', or 'trans-phenomenal."' ${ }^{21}$ The suppositum is not like a Kantian thing-in-itself (noumenon) unknown and beyond our experience. It is indeed something that is given through phenomena, in a sense, present in phenomena. That is why facing various human phenomena, we also have a chance to perceive and grasp the suppositum. Wojtyła underlines this important moment saying, "through all the phenomena that in experience go to make up the whole human being as someone who exists and acts, we perceive - somehow we must perceive - the subject of that

$20 \quad$ Ibid., p. 128.

${ }^{21}$ K. Wojtyła, The person: subject and community, [in:] id., Person and community, op. cit., p. 222. 
existence and activity. Or better, we perceive that the human being is must be - that 'subject." 22

The metaphysical subject, constituting the foundation of the human being and "manifesting" itself through her various activities, plays a vital role in the identity of the person. Talking about identity we mean a kind of basic sameness of the human individual. In contemporary philosophy, especially of the English-speaking provenience, very complex discussions on this topic are conducted. Wojtyła does not delve into them but offers his own proposal. In doing this he does not hesitate to point that, "metaphysical subjectivity, or the suppositum, as transphenomenal and therefore the fundamental expression of the experience of the human being, is also the guarantor of the identity of this human being in existence and activity." ${ }^{23}$ Thus the suppositum guarantees the sameness of the person in two dimensions: in her coming to be and in her enduring through time as well as in her various activities, including acts and happenings. Generally comparing this proposal to ideas of some modern and contemporary thinkers, we must observe that the identity of the person is guaranteed here by a primary dimension of the human being but not by a secondary one(s). The latter would be the case when consciousness, memory and further personal characteristics came into play as main factors.

The suppositum as an expression of metaphysical subjectivity is not detached from a personal subjectivity. Wojtyła tries to sketch what kind of relation is between them. Assuming that the human person is an integrated entity, these two instances of subjectivity must be connected with each other in an essential way. The Polish philosopher observes that the self constitutes itself through actions, including strictly personal acts and other psychosomatic dynamisms that simply happen in her. But this development of the self is possible "because it already is and has been constituted in an essential and fundamental way as a suppositum." 24 The personal subjectivity then depends, to a considerable extent, on the 
metaphysical subjectivity. The instances of the former do not come from the void but stem, in a sense, from a well "established source." From the other side, this relation is made clear when Wojtyła declares, "the suppositum humanum must manifest itself as a human self: metaphysical subjectivity must manifest itself as personal subjectivity." 25

This essential relation leads to some important consequences. As the Polish philosopher points out, "the human being is a person 'by nature. The subjectivity proper to a person also belongs to the human being 'by nature". ${ }^{26}$ The suppositum tends "naturally" to become the person in a strict sense, and vice versa - the personal subjectivity is firmly anchored in the human subjectivity. This thesis, of course, can be at times problematic. There are known examples of people who do not reach a threshold of personal life due to various diseases or health abnormalities. They do not display typical personal characteristics, for example self-consciousness and the faculty of verbal communication. Then can we wonder whether the relation between these two instances of subjectivity is indeed so stringent and necessary. Wojtyła himself deals with this inquiry claiming that a factual manifestation of the relation is not so important. Personal characteristics - as he claims - "reside within the essentially human suppositum." ${ }^{27}$ This residence should be understood metaphysically and not empirically. To make it clear, we can employ a distinction between potentiality and ability. The latter is concerned with a current readiness of the human being to manifest personal characteristics due to the proper development of certain vital organs, for example the brain and nervous system. Potentiality in turn points to a very fundamental orientation to produce such characteristics, which can be subscribed to the human being as such despite her level of development and maturity. Thus we can conclude that Wojtyła draws a relation between the metaphysical

25 Ibid.

26 Ibid.

27 Ibid. In other places he points out that typically personal features like in-selfness and inwardness of human activity and existence are part of the definition of "what is contained virtually in the notion of suppositum humanum." See ibid., p. 227. 
subjectivity and the personal one on the level of potentiality not ability, and hence on the level of metaphysics and not phenomenological insight.

\section{Critical look at the project and its further developments}

Wojtyła's approach to the concept of suppositum is not systematic. There is no separate treatise of his on the issue. In order to reconstruct the philosopher's thinking in this respect, it is necessary to refer to various places in his writings. As we have seen above, remarks and analyses on the issue are scattered and fragmentary. Nevertheless, the notion itself plays quite an important role in Wojtyła's understanding of the person. In fact, it would be difficult to speak about the metaphysics of the person without a notion like this. Consequently, suppositum is necessary to comprehend adequately personal subjectivity as well as the integral picture of the person and her acts.

Nevertheless, the notion of metaphysical subjectivity demands some further clarifications in order to serve its purpose. Introducing this concept, Wojtyła intended to provide a firm foundation for the project of the person. This project in turn was to be a theoretical framework for a reality which is rich in its various phenomena, including rational and free undertakings as well as non-intentional happenings. In short, the person - in his thought - is a highly dynamic reality. If this is the case, then we need to point to its adequate foundation. There are two reasons that speak to this necessity. First, for Wojtyła, to be a person is not to be an emergent reality, as it is understood in contemporary non-reductive naturalism. It means that the person cannot be treated as a reality that arises out of some basic constituents, but is richer and more complex in its being and at the same time irreducible to them. Second, for Wojtyła the foundation of the person is somehow present in further activities: as we mentioned above, the suppositum is transphenomenal. Hence, if phenomena in themselves are rich and diverse so must be their foundation. That is why we need to sketch the understating of the metaphysical subject as a highly dynamic reality, which has a vital relation with the whole activity of the person. In order to do that, we need an adequate and 
a well-defined concept of substance. Wojtyła himself does not provide us with this type of theory because - as we mentioned at the beginning - he was not a fully-fledged metaphysician. We should turn in another direction for this vital support.

In this respect, an interesting contribution is made by the American philosopher W. Norris Clarke. It seems that his original interpretation of Thomas Aquinas's thought can bring some help to our investigation of the person. Wojtyła and Clarke were contemporaries, and both received inspiration from Thomas Aquinas and the Thomistic philosophical tradition but in different ways. Wojtyła was an ethicist and a thinker involved in the philosophy of the human person. Clarke was a metaphysician entertaining a vivid interest in the reality of the human person. Both were also open to non-Thomistic philosophical ideas, especially modern and contemporary ones. Clarke openly makes references to Wojtyła's ideas concerning the person and finds them interesting, novel, and worth of pursuing. ${ }^{28}$ Although Wojtyła did not make explicit reference to Clarke's works, we can employ ideas of the American philosopher and in this way ponder whether we can complement and strengthen the anthropological project of the Polish thinker. At any rate, Clarke has something important to offer to Wojtyła, especially as far as the metaphysical foundations of the person are concerned.

In the Acting person, Wojtyła acknowledges that the metaphysical subject is a dynamic reality. He indicates directly that, "the suppositum is not only inserted ('lays') under a whole dynamism of the human being the person - but also constitutes this dynamism as a dynamic source." 29 As we have set forth above, the Polish philosopher indicates that this type of character of the metaphysical subject significantly influences the personal subject and her acts. The problem is that we do not know any

28 W. N. Clarke, Person and being, Milwaukee 1993. He also makes other references to the thoughts of the Polish thinker. See W. N. Clarke, John Paul II: the complementarity of faith and philosophy in the search for truth, "Communio" 26 (1999), p. 557-570; id., The integration of personalism and Thomistic metaphysics in twenty-first-century Thomism, [in:] id., The creative retrieval of St. Thomas Aquinas. Essays in Thomistic philosophy, new and old, New York 2009, p. 226-231.

29 K. Wojtyła, Osoba i czyn, op. cit., p. 124. 
other details as to how this happens. We need to determine the dynamic character of the suppositum itself and its relation to the personal subject.

Norris Clarke, in his reading of Aquinas, points out that the medieval philosopher understood each living entity as a dynamic and selfmanifesting being. In this understanding, there is no place for a passive existence enclosed in itself, limited to its inner sphere and to a mysterious, unknowable enduring. If this were so, "there would be no way for anything else to know that it exists; it would make no difference at all to the rest of reality; practically speaking, it might just as well not be at all - it would in fact be indistinguishable from non-being. ${ }^{30}$ Clarke underlines the close and essential relation between existence and action. As he puts it, "to be and to be active, though conceptually distinct, are inseparable." ${ }^{31}$ The activity here is comprehended very broadly, including very basic manifestations of existing things, but taking place at all levels of its existence. The American philosopher is even convinced that "the full meaning of 'to be' is not 'to be present', but 'to be actively present'." 32 At any rate, existence is a dynamic process and hence we have no better means to grasp and characterize it as by a description of a set of actions, which make it up.

Such an understanding of the existence enables us to formulate a concept of substance. Both Wojtyła and Clarke recognize a helping role of the concept in the philosophy of the human person, which is not a typical attitude in contemporary philosophy. As it is widely known, there is great skepticism among thinkers as to the suitability of the notion in an inquiry on the human being. Nevertheless, the substance is understood here not as a passive and inert reality - which is a common objection directed to it - but as a highly dynamic one. Clarke straightforwardly declares that, "to be in the world of real existence is to be substance-inrelation." ${ }^{33}$ The dynamic character of the existent is instantiated by various

$30 \quad$ W. N. Clarke, Person and being, op. cit., p. 12-13.

31 Ibid., p. 13.

32 Ibid.

33 W. N. Clarke, To be is to be substance-in-relation, [in:] id., Explorations in metaphysics. Being. God. Person, Notre Dame 1994, p. 114. 
relations, which a given being establishes. These relations are directed to itself as well as to others, because - as Clarke puts it - "it exists both as in-itself and as toward others." ${ }^{34}$

In the tradition of Thomistic metaphysics this way of philosophizing can be problematic. There is a clear distinction here between the meaning and roles of substance and relation. While talking about the existence of a thing, a language of substance plays an essential role, whereas it is not so in the case of relation language. Generally, relation is considered as accidental to a given thing. This logic applies to persons as well. Thomas Aquinas, while pondering about God as a person, points out that "the word person is the idea of a 'first' substance. Therefore this word person signifies a 'first' substance, than which nothing is more absolute, since it is self-existent. Therefore the word person does not signify a relation, but something absolute. [...] If then person signifies substance which is a self-existent being, it cannot signify a relation.. ${ }^{35}$ Although according to Aquinas, in God relations are absolute ("in God relation is really the same as the essence"), the distinction between the person-substance and a relation applies to all human persons. Therefore, Clarke's claim "to be is to be substance in relation" must be specified. In order to do that, we should distinguish between various relations, say, external and internal. External relations, which seem to be on Thomas Aquinas's mind, are indeed secondary. It is not so with internal relations, namely relations which are constitutive for the person-substance itself.

Now we can return to Wojtyła's concept of suppositum. The question is whether we can apply Clarke's analysis to the understanding of a metaphysical subject and if so, how helpful is it? The Polish philosopher directly introduces a distinction between the metaphysical subject and a personal one. Clarke does not operate such a distinction limiting his undertaking to the discrimination between nature and the person. Nevertheless, it does not amount to a major obstacle. We can argue that if the understanding of the substance as a dynamic entity is referred to

$34 \quad$ Ibid., p. 108.

35 Thomas Aquinas, On the power of God (Questiones Disputatae de Potentia), Q. IX, A. IV. 
the person, it is referred to the whole being, including her metaphysical and personal subjectivity, and the level of the nature as well as the level of the person. In other words, both the former and the latter are in relation, though in different ways.

Let us focus on the notion of the human substance, which can be characterized by dual subjectivity. If the metaphysical and personal subjects, considered together, constitute a highly dynamic reality it means that it establishes a set of "inner" as well as "outer"relations. In this sense it would live up to Clarke's postulate of existing in-itself and toward others. The inner relations then would have intra-being characters and are established when the human being comes to be, and is developing and maturing according to her proper telos. These relations exist between the metaphysical and personal subject. Although the former tends to constitute the latter (to express itself in the latter), and what is ontologically given is "taken over" by the personal, there still remains a slight difference and contrast between them. Many personalists point out that the term "substance" contains in itself something cosmological (appearing in various forms) which is not totally congruent with the personal (understood as a complex sphere). ${ }^{36}$ In Wojtyła's analyses this duality is underlined when he considers the cosmological, which is reducible, and the personal, which is irreducible. The Polish thinker is aware that the personal does not "absorb" the cosmological completely, but they "need" one another, and hence they remain mutually in relation. ${ }^{37}$ Thus there is

36 See J. F. Crosby, The selfhood of the human person, Washington, D.C, 1996 (Polish translation: Zarys filozofii osoby. Bycie soba, trans. B. Majczyna, Kraków 2007); M. J. Burgos, El personalismo. Autores y temas de una filosofía nueva, Madrid 2003, ch. V (Polish translation: Personalizm. Autorzy i tematy nowej filozofii, trans. K. Koprowski, Warszawa 2010).

37 This theme is widely analyzed by Wojtyła in his influential paper Subjectivity and the irreducible in the human being, [in:] K. Wojtyła, Person and community, op. cit., p. 209-217. Suggestions appear there that allow us to talk about these inner relations, when the philosopher points to an insufficiency of the metaphysical definition of the person. He reasons as follows, "[...] the Boethian definition mainly marked out the 'metaphysical terrain' - the dimension of being - in which personal human subjectivity is realized, creating, in a sense, a condition for 'building upon' this terrain on the basis of experience" (ibid., p. 212). Or in another place where Wojtyła points out that 
not a complete fusion between suppositum and the personal subject and that is why they remain related within the human substance.

The outer relations are toward other subjects. They provide the person with opportunities to actualize and manifest herself in all her personal richness and complexity. They create a sphere of "social between" where the person can unfold her many potentialities. But these relations are accidental and secondary in the logical (absolute) order, that is, as far as the structure of the person is concerned. In this sense Aquinas was right excluding relation from a strict definition of the person. Outer interactions cannot constitute the personal being but they are helpful in her manifestation in the social sphere. However, when we look from the latter standpoint, we can claim that this is a sphere where we get to know the person in the first place. Hence, in the phenomenal (epistemological) order - which was important for Wojtyła - outer relations can be considered primary and necessary. ${ }^{38}$

\section{Conclusions}

The concept of suppositum has a long philosophical pedigree, especially in Aristotelian and Thomistic philosophy. Karol Wojtyła accepted that as a part of the philosophical environment within which he was educated. Nevertheless, he was not uncritical. On the one hand, the Polish philosopher was aware of the positive and constructive role the concept can play in the exploration of the human person. On the other, Wojtyła intended to bring out all possible implications connected with the concept of the metaphysical subject and, at the same time, was cautious and avoided some metaphysical "extremities." Thus, for example, the suppositum is not like the Cartesian self-enclosed and self-sufficient substance. Neither is it the Lockean inert, unknowable substratum. Wojtyła's thinking of the

what is personal is complementary to what is cosmological suggesting an inner relationality in the person. Ibid., p. 213.

38 W. N. Clarke, Action as self-revelation of being. A central theme in in the thought of St. Thomas, [in:] id., Explorations in metaphysics, op. cit., p. 47. 
suppositum is also far from the notion of a bundle of personal characteristics. The latter easily leads to a thesis that the personal subject can exist without the metaphysical one. Understandably such a solution would be unacceptable for him.

The Polish philosopher tries to reconcile two essential attributes concerning the person, namely that she is both a substantial and dynamic reality. He did not explained in detail how they fit together, but drawing on the ideas of Norris Clarke, we can solve this nexus pointing to a notion of relation. Here, the inner relations, necessary and essential, are especially helpful. They shed some light on the association of the suppositum with the personal subject. They amount to intra-being connections, which are fundamental for the person and without which there is no possibility of inter-being or inter-personal relations.

Summing up we can argue that the concept of the dynamic metaphysical subject, in an advanced form, can be vital in supporting the philosophy of the human person. Considered together with the personal subject, it uncovers two pillars in the mature understanding of the human being: substantiality and relationality. Substantiality, due to its inner relationality, makes the human being a highly dynamic reality.

\section{Bibliography}

Aquinas Thomas, On the power of God (Questiones Disputatae de Potentia), Q. IX, A. I-IX. Burgos M. J., El personalismo. Autores y temas de una filosofía nueva, Madrid 2003. Polish translation of this book is: Personalizm. Autorzy i tematy nowej filozofi, trans. K. Koprowski, Warszawa 2010.

Clarke W. N., Action as self-revelation of being. A central theme in in the thought of St. Thomas, [in:] W. N. Clarke, Explorations in metaphysics. Being. God. Person, Notre Dame 1994, pp. 45-64.

Clarke W. N., John Paul II: the complementarity of faith and philosophy in the search for truth, "Communio" 26 (1999), pp. 557-570. 
Clarke W. N., The integration of personalism and Thomistic metaphysics in twenty-first-century thomism, [in:] W. N. Clarke, The creative retrieval of St. Thomas Aquinas. Essays in Thomistic philosophy, new and old, New York 2009, pp. 226-231.

Clarke W. N., To be is to be substance-in-relation, [in:] W. N. Clarke, Explorations in metaphysics. Being. God. Person, Notre Dame 1994, pp. 102-122.

Clarke W. N., Person and being, Milwaukee 1993.

Crosby J. F., The selfhood of the human person, Washington, D.C, 1996. Polish translation is: Zarys filozofii osoby. Bycie sobą, trans. B. Majczyna, Kraków 2007.

Frossard A., "Be not afraid": pope John Paul II speaks out on his life, his beliefs, and his inspiring vision for humanity, trans. J. R. Foster, New York 1984.

John Paul II, Fides et ratio.

Krąpiec M. A., Książka kardynała Karola Wojtyly monografia osoby jako podmiotu moralności, "Analecta Cracoviensia" 5-6 (1973-1974), pp. 57-61.

Reimers A. J., Karol Wojtyta's aims and methodology, presentation delivered at the conference Christianity confronts modernity, December 12-14, 2013, University of Notre Dame (USA), publication pending.

Wais K., Ontologja czyli metafizyka ogólna, Lwów 1926.

Wojtyła K., In search of the basis of perfectionism in ethics, [in:] K. Wojtyła, Person and community. Selected essays, trans. T. Sandok, New York 1993, p. 45-56.

Wojtyła K., Ocena możliwości zbudowania etyki chrześcijańskiej przy założeniu systemu Maxa Schelera, [in:] K. Wojtyła, Zagadnienie podmiotu moralności, Lublin 1991, p. 11-128.

Wojtyła K., Osoba i czyn, [in:] K. Wojtyła, "Osoba i czyn” oraz inne studia antropologiczne, Lublin 1994, p. 43-344. English translation of the book is: The acting person, trans. A. Potocki, A.-T. Tymieniecka, Boston 1979.

Wojtyła K., Subjectivity and the irreducible in the human being, [in:] K. Wojtyła, Person and community. Selected essays, trans. T. Sandok, New York 1993, pp. 209-217.

Wojtyła K., The person: subject and community, [in:] K. Wojtyła, Person and community. Selected essays, trans. T. Sandok, New York 1993,, p. 219-161.

Wojtyła K., Elementarz etyczny, Lublin 1999.

Wojtyła K., Love and responsibility, trans. H. T. Willetts, San Francisco, 1981. Polish original of the book is: Miłość i odpowiedzialność, Lublin 1960.

Wojtyła K., Wykłady lubelskie, Lublin 1985. 